\title{
FLOWER AND FOLIAR ANALYSIS FOR PROGNOSIS OF SWEET CHERRY NUTRITION. INFLUENCE OF DIFFERENT ROOTSTOCKS
}

\author{
S. Jiménez ${ }^{1}$, A. Garín', Y. Gogorcena ${ }^{1}$, J.A. Betrán ${ }^{2}$ and M.A. Moreno ${ }^{1}$ \\ ${ }^{1}$ Departamento de Pomología, Estación Experimental de Aula Dei (Consejo Superior de \\ Investigaciones Científicas), Apdo. 202, 50080 Zaragoza, Spain \\ ${ }^{2}$ Laboratorio Agroambiental (Diputación General de Aragón), Apdo. 202, 50080 Zaragoza, \\ Spain
}

\section{ABSTRACT}

This research was aimed to study the interest of flower analysis as a tool for the prognosis of nutritional deficiencies on cherry trees and confirm the influence of rootstock on the mineral uptake by tree. This type of diagnosis is compared with foliar analysis. The trial was established on a calcareous clay-loam soil, where 'Sunburst' cultivar on eight rootstocks: CAB 6P, CAB 11E, Masto de Montañana 9 (MM 9), MaxMa 14, MaxMa 97, GM 61/1 (Damil), Colt and Sainte Lucie GF 64 (SL 64). The mineral elements analysed were: N, P, K, $\mathrm{Ca}, \mathrm{Mg}, \mathrm{Fe}, \mathrm{Mn}, \mathrm{Zn}, \mathrm{Na}$ and $\mathrm{Cu}$.

Rootstock influence on mineral nutrient uptake was observed for all mineral elements studied in flowers and for N, P, K, Ca, Mg, Fe, Mn and $\mathrm{Cu}$ in leaves. The N, Ca and Mn concentrations in flowers and leaves were significantly correlated, being more noticeable the correlation between leaf and flower Mn concentration $(\mathrm{r}=0.86 ; p \leq 0.01)$. A significant correlation was also found between the yield of the following year and element concentration in leaves.

In general, the $P$. cerasus rootstocks (CAB 6P, CAB 11E and MM 9) showed values of leaf mineral elements more adequate, and also higher values of leaf chlorophyll concentration.

\section{INTRODUCTION}

Foliar analysis is the most common method to determine nutritional status in plants. However, the prognosis of iron chlorosis or other deficiencies by foliar analysis or SPAD reading is performed, on many occasions, too late to apply efficiently correcting measures 
before harvesting $(1,2)$. Furthermore, leaf prognosis of iron chlorosis is imprecise in several cases, as the diagnosis based in total $\mathrm{Fe}$ as in the various parts $(3,4)$.

Several researchers have studied the efficiency of floral analysis $(1,5)$, as an early diagnosis tool of the nutritional status in peach trees. Analysis of mineral content in flowers would allow the diagnosis of potential deficiencies or excesses in time to be corrected with more efficiency (6).

The rootstock influence on the mineral uptake by cherry trees has been demonstrated $(7,8,9)$. Thus, the use of tolerant rootstocks would prevent nutritional disorders that cause economic loss for the fruit growers.

The present study was carried out with 'Sunburst' sweet cherry, grafted on different rootstocks, growing on heavy and calcareous soil conditions. The objective was to study the feasibility of using the mineral analysis of flowers, as a prognosis tool for the nutritional deficiencies. Our second objective was to assess the influence of rootstock on the mineral nutrient uptake by cherry rootstocks.

\section{MATERIALS AND METHODS}

\section{Plant Material}

Eight clonal rootstocks were compared in one trial established in the winter of 1988-1989. They were grafted in situ with 'Sunburst' sweet cherry cultivar during the Summer of 1989.

The rootstocks under evaluation included three sour cherry (Prunus cerasus) selections: CAB 6P, CAB 11E, and Masto de Montañana 9 (MM 9); one selection each of P. mahaleb: Sainte Lucie GF 64 (SL 64), and P. dawyckensis: GM 61/1 (Damil); a P. avium x P. pseudocerasus hybrid: Colt; and two other selections considered to be of P. mahaleb x P. avium parentage: MaxMa 14 and MaxMa 97. 


\section{Field Trial}

The trial was carried out at the Estación Experimental de Aula Dei (Zaragoza, Spain) on calcareous soil, with $35 \%$ total calcium carbonate, $8 \%$ active lime, $\mathrm{pH}$ in water 8.0 , and a clay-loam texture.

Trees were planted at $5 \times 4.5 \mathrm{~m}$, and allowed to develop naturally with minimal pruning throughout the experiment. The orchard was managed following the usual local procedures. The plot was level-basin irrigated every 12 days during the peak of the summer. The experiment was established in a randomised block design with five single-tree replications for each scion/stock combination. Guard rows were used to preclude edge effects.

\section{Chlorophyll Analysis}

The chlorophyll (Chl) concentration per unit leaf area was estimated in the field, using a SPAD 502 meter (Minolta Co., Osaka, Japan). After calibration, SPAD measurements were converted into $\mathrm{Chl}$ concentration per unit of leaf area $\left(\mathrm{nmol} \mathrm{Chl} \mathrm{cm}{ }^{-2}\right)$. Thirty leaves per tree, from extension shoots located all around the crown, were measured with the SPAD to obtain an average leaf $\mathrm{Chl}$ concentration representative of the leaves belonging to the outer part of the tree canopy. Measurements were carried out at 30, 70, 90 and 120 days after full bloom (DAFB) in 2001. In addition, leaf dry weight per unit area (W/LA) was determined from samples of undamaged adult leaves from extension shoots of the scion that were collected at 90 DAFB. Fourty leaves per tree were sampled and their area and percentage moisture content recorded.

\section{Mineral Analysis}

Leaf and flower mineral element concentrations were determined in 2001 , i.e. the 12 th year after grafting. Flower sampling was done at full bloom at the end of March.

Leaf sampling was done at 90 DAFB (approximately 3-4 weeks after harvest). Leaf samples were collected from extension shoots of trees of five blocks, i.e. five single-tree replications of each graft combination. 
The mineral elements of the dried samples were measured using the methods of C.I.I. (10) and C.I.I. et al. (11). Total $\mathrm{N}$ was determined by Kjeldahl analysis; P was analysed by the phospho vanadate colorimetric method; $\mathrm{K}$ by atomic emission spectroscopy; and $\mathrm{Ca}, \mathrm{Mg}, \mathrm{Fe}$, $\mathrm{Mn}, \mathrm{Cu}, \mathrm{Na}$ and $\mathrm{Zn}$ by atomic absorption spectroscopy (Pye Unicam SP9).

\section{Deviation from Optimum Percentage}

The DOP index (Deviation from Optimum Percentage) was estimated for the diagnosis of the nutritive status of the trees (12). The DOP index was calculated from the leaf analysis at 90 DAFB by the following mathematical expression:

$D O P=\frac{C \times 100}{C_{r e f}}-100$

Where $\mathrm{C}$ is the nutrient concentration in the sample to be studied and $\mathrm{C}_{\text {ref }}$ is the nutrient concentration considered as optimum, both values given on a dry matter basis. The $\mathrm{C}_{\text {ref }}$ has been taken from optimum values proposed by Leece (13). The $\Sigma$ DOP is obtained by adding the values of DOP indices irrespective of sign. The larger the $\Sigma$ DOP, the greater the intensity of imbalances among nutrients.

\section{Analysis of Data}

Data were evaluated by analysis of variance with SPSS 10.0 (14). When the F test was significant, means were separated by Duncan's Multiple Range test $(P \leq 0.05)$.

\section{RESULTS AND DISCUSSION}

The influence of rootstocks on flower and leaf mineral elements concentration was statistically significant (Table 1).

\section{Floral Mineral Nutrients}

Differences in macronutrients concentrations of flowers were significant among rootstocks (Table 1). The $\mathrm{N}$ concentration was higher on Damil and Colt although differences were not significant when compared with CAB 11E, MaxMa 97 and SL 64. Floral P concentration was higher on SL 64, lower on CAB 6P, and intermediate, but not significantly different from the 
other two rootstocks, on CAB 11E, MM 9, MaxMa 14, MaxMa 97, Damil and Colt. The K concentration was greater on Damil although this did no differ significantly from SL 64 . The Ca concentration was significantly higher on Colt rootstock. This tendency of trees on Colt to higher flower $\mathrm{Ca}$ concentration has been previously reported for 'Van' sweet cherry when it was grafted on three rootstocks (15). Flower Mg concentration was greater on SL 64, although differences were not significant when compared with MaxMa 14, MaxMa 97, Damil, Colt and CAB 6P.

Micronutrient concentration was significantly influenced by rootstock. As previously reported (15), the Fe concentration in flowers was greater on SL 64, probably due to the better adaptation of $P$. mahaleb species in calcareous soils. Flower Mn concentration was highest on $P$. cerasus rootstocks (CAB 6P, CAB 11E and MM 9), especially when compared with MaxMa 97, MaxMa 14 and SL 64. Similar tendency was observed in leaves in a previous work (16). As previously reported (15), the Fe concentration in flowers was greater on SL 64, probably due to the better adaptation of $P$. mahaleb species in calcareous soils. The Zn concentration was higher on $\mathrm{CAB} 6 \mathrm{P}$, although this did no differ significantly from $\mathrm{CAB}$ 11E, MM 9, MaxMa 14 and SL 64, while the concentration was lower on MaxMa 97. The Na concentration was higher on $\mathrm{CAB} 11 \mathrm{E}$, although differences were not significant when compared with MM 9, MaxMa 14, Damil and SL 64. The greatest flower Cu concentration was shown on SL 64, although this did no differ significantly from P. cerasus rootstocks and MaxMa 14.

\section{Leaf Mineral Nutrients}

The $\mathrm{N}$ concentration was higher on $P$. cerasus rootstocks (CAB 6P, CAB 11E and MM 9) and MaxMa 97, lower on MaxMa 14, Damil and Colt and intermediate, but not significantly different from the other seven rootstocks, on SL 64 (Table 1). The lowest leaf P concentration was shown on Damil, although differences were not significant when compared with Colt, MM 9 and CAB 11E. In this year and the previous years (1997 and 1998), the K concentration was lower on Damil and Colt rootstocks, whereas the Mg concentration was higher on the last one. The leaf Ca concentration was greater on Colt and SL 64. Colt appears to induce more leaf $\mathrm{Ca}$ concentration on cherry cultivars, as previously reported $(8,16)$. 
The $\mathrm{Zn}$ and $\mathrm{Na}$ concentration of leaves were not significant among rootstocks. The Fe concentration was lower on Damil, although differences were not statistically significant when compared with CAB 6P rootstock. However, it was greater on MaxMa 97 although this did no differ significantly from CAB 11E, MM 9, MaxMa 14, Colt and SL 64. The Mn concentration was higher on $\mathrm{CAB} 6 \mathrm{P}$ and $\mathrm{CAB} 11 \mathrm{E}$. They were followed by MM 9, but the Mn concentration did not differ from that of Damil. In this year and the previous years (1997 and 1998), rootstocks differences were similar for the leaf $\mathrm{Mn}$ concentration. The lowest $\mathrm{Cu}$ concentration was shown on Damil and Colt.

Significant correlation between yield of the following year (2002) and leaf mineral concentration for $\mathrm{N}(\mathrm{r}=0.62 ; p \leq 0.01), \mathrm{K}(\mathrm{r}=0.45 ; p \leq 0.01), \mathrm{Fe}(\mathrm{r}=0.45 ; p \leq 0.01)$ and $\mathrm{Cu}$ $(\mathrm{r}=0.53 ; p \leq 0.01)$ were found. For the last year, yield was much more abundant. However, in the previous year (2001), no significant correlation was found, probably due to the small yield.

\section{DOP}

With the aim of determining the optimum mineral nutrition, the DOP index was determined from leaf mineral elements at 90 DAFB. This index provides similar information to the Diagnosis and Recommendation Integrated System (DRIS) (17).

Leaf $\mathrm{N}$ concentrations were slightly lower than optimum in all rootstocks (13), except on CAB 6P, MM 9 and MaxMa 97. An excessive P concentration was found in all rootstocks, except on Damil, Colt and MM 9. Colt showed values of K concentration slightly lower than adequate (13). However, this rootstock and SL 64 showed values of Ca higher than optimum. Leaf $\mathrm{Mg}$ concentrations were consistently adequate for all rootstocks, as previously reported (16). All rootstocks showed a relative deviation to the optimum concentration of Fe (13), although it was more important on Damil. MaxMa 97 showed values of Mn slightly lower than adequate. Leaf $\mathrm{Zn}$ concentration was higher than optimum for MaxMa 14. Leaf $\mathrm{Na}$ and $\mathrm{Cu}$ concentrations were consistently adequate (13) for all rootstocks.

According to the $\Sigma$ DOP index, the CAB $11 \mathrm{E}$ rootstock showed better balanced nutritional values, although the differences were not statistically significant when compared with the other P. cerasus rootstocks (CAB 6P and MM 9). A significant and negative correlation was 
found between $\Sigma$ DOP index and yield in $2001(\mathrm{r}=0.36 ; p \leq 0.05)$, if the values of Damil rootstock are not considered (extremely low yielding rootstock).

\section{Leaf Characteristics}

The amount of wet weight, dry weight and dry matter per unit of leaf area $\left(\mathrm{g} . \mathrm{m}^{-2}\right)$ were not significantly influenced by rootstocks. However, leaf humidity percentage were, in general, lower on CAB 11E and MaxMa 97 rootstocks (data not shown).

To determine differences among rootstocks in the leaf chlorophyll concentration, SPAD readings in leaves of the cultivar were obtained. The results showed that it was affected by the rootstock (Figure 1).

Leaf SPAD readings were, generally, higher for P. cerasus (CAB 11E, CAB 6P and MM 9), MaxMa rootstocks and SL 64, but they were lower for Colt and Damil. All rootstocks increased the chlorophyll concentration to 90 DAFB, whereas from 90 to 120 DAFB they showed a slight decrease, except for SL 64 rootstock, that showed a slight increase in the chlorophyll concentration.

\section{Comparison among Flower and Leaf Mineral Analysis and Chlorophyll Concentration}

The range of variation of $\mathrm{Na}$ and $\mathrm{Zn}$ concentration in flowers was greater than that of leaves. As before indicated, rootstocks had no effect on leaf $\mathrm{Zn}$ and $\mathrm{Na}$ concentration. In contrast, flower analysis revealed differences among rootstocks for these elements.

When mineral element concentrations of flowers are compared with those obtained in leaves, only the values of $\mathrm{Ca}, \mathrm{Mg}$ and $\mathrm{Mn}$ appeared lower than in leaves. Similar results have been reported by other researchers for pear (18), peach (5) and cherry trees (15).

Significant correlation between flower and foliar mineral concentration for $\mathrm{N}(\mathrm{r}=-0.50$; $p \leq 0.01), \mathrm{Ca}(\mathrm{r}=0.74 ; p \leq 0.01)$ and $\mathrm{Mn}(\mathrm{r}=0.86 ; p \leq 0.01)$ was found.

Manganese deficiency has been reported for cherry grown in calcareous soils $(8,19)$, probably due to the insolubilization of this element in these type of soils. The good 
correlation between leaf and flower Mn concentration (Figure 2) suggest that Mn flower analysis could be used to detect and treat any deficiencies at an earlier stage in cherry trees.

In this study, correlation between leaf and flower Fe concentration was not found statistically significant. However, other authors found it was statistically significant for peaches (6).

The chlorophyll concentration in leaves, determined before and after leaf mineral analysis, was positively correlated with leaf $\mathrm{N}, \mathrm{K}, \mathrm{Fe}, \mathrm{Cu}$ and $\mathrm{Zn}$ concentration. The Fe floral concentration was positively correlated with the chlorophyll concentration in leaves at 30 DAFB $(\mathrm{r}=0.33 ; p \leq 0.05), 70$ DAFB $(\mathrm{r}=0.36 ; p \leq 0.05)$ and 120 DAFB $(\mathrm{r}=0.31 ; p \leq 0.05)$. This was also found for peach trees (6). Interactions between Fe and other micronutrients also encourage Fe deficiency. Thus, the chlorosis observed on Damil and Colt cannot be simply explained as Fe deficiency because the mineral content for other elements as N, P, K, Zn and $\mathrm{Cu}$, is markedly affected. On the other hand, the chlorophyll concentration in leaves was negatively correlated with the $\mathrm{Mg}$ and $\mathrm{Ca}$ concentration of leaves, as previously reported for peach (19) and for apple (2) trees. The tendency of higher values for $\mathrm{Mg}$ and $\mathrm{Ca}$ and less chlorophyll in leaves on Colt and Damil was also reported in previous years (1997 and 1998) (16)

\section{CONCLUSION}

Rootstock influence on mineral nutrient uptake was found for all mineral elements concentration in flowers and for most of them in leaves. The N, Ca and Mn concentrations in flowers and leaves were significantly correlated. The use of flower analysis would permit the early detection and correction of any deficiency of $\mathrm{Mn}$.

P. cerasus rootstocks showed a more adequate level of mineral nutrients, probably due to better adaptation to heavy and calcareous soils, that also lead to higher concentration of chlorophyll. In contrast, Damil and Colt rootstocks showed the worse adaptation to those conditions, with an inadequate uptake of mineral nutrients and lower chlorophyll concentration in leaves, especially when the growing season is advanced. 


\section{ACKNOWLEDGEMENTS}

Financial support was provided by Comisión Interministerial de Ciencia y Tecnología (AGL2001-2303-C02-01 project). S. Jiménez and Y. Gogorcena were supported by a I3P grant from CSIC/FSE and a Ramón y Cajal contract from MCYT, respectively. We thank Dr. J. Pinochet for critical review of the manuscript. We gratefully acknowledge J. Aparicio and J. Pérez for the management of plant material in the orchard.

\section{REFERENCES}

(1) Sanz, M.; Pascual, J.; Machín, J. Prognosis and correction of iron chlorosis in peach trees: Influence on fruit quality. J. Plant Nutr. 1997, 20 (11), 1567-1572.

(2) Sanz, M.; Pascual, J.; Machín, J. Análisis floral de hierro para la predicción de clorosis férrica en manzano. Información Técnica Económica Agraria 1998, 94 (3), 158-164.

(3) Abadía, J.; Nhisio, J.N.; Monge, E.; Montañés, L.; Heras, L. Mineral composition of peach leaves affected by iron clorosis. J. Plant Nutr. 1985, 8 (8), 697-707.

(4) Abadía, A.; Sanz, M.; De Las Rivas, J.; Abadía, J. Photosynthetic pigments and mineral composition of iron deficient pear leaves. J. Plant Nutr. 1989, 12 (7), 827-838.

(5) Sanz, M.; Montañés, L. Flower analysis as a new approach to diagnosing the nutritional status of the peach tree. J. Plant Nutr. 1995, 18, 1667-1675.

(6) Abadía, J.; Tagliavini, M.; Grasa, R.; Belkhodja, R.; Abadía, A.; Sanz, M.; Araujo, E.; Tsipouridis, C.; Marangoni, B. Using the flower Fe concentration for estimating chlorosis status in fruit tree orchards: a summary report. J. Plant Nutr. 2000, 23, 2023-2033.

(7) Facteau, T.J.; Chesnut, N.E.; Rowe, K. E. Tree fruit size and yield of 'Bing' sweet cherry as influenced by rootstock, replant area, and training system. Sci. Hortic. 1996, 67, 13-26.

(8) Moreno, M.A.; Montañés, L.; Tabuenca, M.C.; Cambra, R. The performance of Adara as a cherry rootstock. Sci. Hortic. 1996, 65, 58-91.

(9) Neilsen, G; Kappel, F. 'Bing' Sweet cherry leaf nutrition is affected by rootstock. HortScience 1996, 31, 1169-1172.

(10) C.I.I. Comité Inter-Institutos para el estudio de técnicas analíticas. Métodos de referencia para la determinación de elementos minerales en vegetales. Anales de Edafología y Agrobiología 1969, 38, 403-417. 
(11) Comité Inter-Institutes (C.I.I.); Pinta, M.; DeWaele, G. Etalons végétaux pour l'analyse foliaire. In P. Kozma; Le contrôle de l'alimentation des plantes cultivées; Akadémiai Kiadó; Budapest, 1975; 159-172.

(12) Montañés, L.; Heras, L.; Sanz, M. Desviación del Óptimo Porcentual (DOP): Nuevo índice para la interpretación del análisis vegetal. An. Aula Dei 1991, 20 (3-4), 93-107.

(13) Leece, D. Diagnostic leaf analysis for stone fruits. 5. Sweet Cherry. Aust. J. Exp. Agric. Anim. Husb. 1975, 15, 118-122.

(14) Norusis, M.S.J. Statistical package for the social sciences/PC+ for the IBM PC/XT/AT.SPSS Inc. Chicago IL. 1999.

(15) Betrán, J.A.; Val, J.; Montañés Millán, L.; Monge, E.; Moreno, M.A. Influence of rootstock on the mineral concentrations of flowers and leaves from sweet cherry. Acta Hortic. 1997, 448, 163-167.

(16) Moreno, M.A.; Adrada, R.; Aparicio, J. and Betrán J.A. Performance of 'Sunburst' sweet cherry grafted on different rootstocks. J. Hortic. Sci. \& Biotech. 2001, 76, 167-173.

(17) Davee, D.E.; Righetti, T.L.; Fallahi, E.; Robbins, S. An evaluation of the DRIS approach for identifying mineral limitations on yield in 'Napolean' sweet cherry. J. Amer. Soc. Hort. Sci. 1986, 111 (6), 988-993.

(18) Sanz, M.; Carrera, M.; Montañés, L. The possibility of using floral analysis to diagnose the nutritional status of pear trees. Acta Hortic. 1994, 367, 290-295.

(19) Belkhodja, R.; Sanz, M.; Abadía, A.; Abadía, J. Effect of chlorosis level on the nutrient concentration in flowers and leaves of peach along the season. Acta Hortic. 1997, 448, 360. 
Table 1. Rootstock effects on leaf mineral element concentrations of 'Sunburst' sweet cherry at 90 days after full bloom, at the 12th year after grafting. Results for N, P, K, Ca and Mg are expressed as percentage of dry matter and for Fe, Mn, and Zn, as mg.kg-1.

\begin{tabular}{|c|c|c|c|c|c|c|c|c|c|c|}
\hline \multirow[b]{2}{*}{ Rootstock } & \multicolumn{2}{|c|}{$\mathrm{N}$} & \multicolumn{2}{|c|}{$\mathrm{P}$} & \multicolumn{2}{|c|}{$\mathrm{K}$} & \multicolumn{2}{|c|}{$\mathrm{Ca}$} & \multicolumn{2}{|c|}{$\mathrm{Mg}$} \\
\hline & Flower & Leaf & Flower & Leaf & Flower & Leaf & Flower & Leaf & Flower & Leaf \\
\hline CAB 6P & $3.37 \mathrm{a}$ & $2.2 \mathrm{~b}$ & $0.44 \mathrm{a}$ & $0.31 \mathrm{bcd}$ & $2.18 \mathrm{ab}$ & $2.5 \mathrm{~b}$ & $0.32 \mathrm{ab}$ & $1.8 \mathrm{ab}$ & $0.184 \mathrm{abc}$ & $0.43 \mathrm{abc}$ \\
\hline CAB $11 \mathrm{E}$ & $3.46 \mathrm{ab}$ & $2.1 \mathrm{~b}$ & $0.48 \mathrm{ab}$ & $0.27 \mathrm{abc}$ & $2.23 \mathrm{abc}$ & $2.5 \mathrm{~b}$ & $0.31 \mathrm{ab}$ & $1.9 \mathrm{ab}$ & $0.180 \mathrm{ab}$ & $0.42 \mathrm{ab}$ \\
\hline MM 9 & $3.36 \mathrm{a}$ & $2.2 \mathrm{~b}$ & $0.47 \mathrm{ab}$ & $0.24 \mathrm{ab}$ & $2.16 \mathrm{a}$ & $2.6 \mathrm{~b}$ & $0.32 \mathrm{ab}$ & $1.8 \mathrm{ab}$ & $0.162 \mathrm{a}$ & $0.38 \mathrm{a}$ \\
\hline MaxMa 14 & $3.41 \mathrm{a}$ & $1.9 \mathrm{a}$ & $0.48 \mathrm{ab}$ & $0.36 \mathrm{~d}$ & $2.34 \mathrm{bc}$ & $2.4 \mathrm{~b}$ & $0.33 \mathrm{ab}$ & $2.2 \mathrm{~b}$ & $0.193 \mathrm{bc}$ & $0.48 \mathrm{bcd}$ \\
\hline MaxMa 97 & $3.54 \mathrm{ab}$ & $2.2 \mathrm{~b}$ & $0.48 \mathrm{ab}$ & $0.32 \mathrm{~cd}$ & $2.36 \mathrm{c}$ & $2.5 \mathrm{~b}$ & $0.30 \mathrm{a}$ & $1.6 \mathrm{a}$ & $0.200 \mathrm{bc}$ & $0.36 \mathrm{a}$ \\
\hline Damil & $3.65 \mathrm{~b}$ & $1.8 \mathrm{a}$ & $0.47 \mathrm{ab}$ & $0.23 \mathrm{a}$ & $2.54 \mathrm{~d}$ & $1.6 \mathrm{a}$ & $0.32 \mathrm{ab}$ & $1.8 \mathrm{ab}$ & $0.203 \mathrm{bc}$ & $0.50 \mathrm{~cd}$ \\
\hline Colt & $3.67 \mathrm{~b}$ & $1.8 \mathrm{a}$ & $0.48 \mathrm{ab}$ & $0.24 \mathrm{ab}$ & $2.27 \mathrm{abc}$ & $1.2 \mathrm{a}$ & $0.38 \mathrm{c}$ & $3.1 \mathrm{c}$ & $0.205 \mathrm{bc}$ & $0.73 \mathrm{e}$ \\
\hline \multirow[t]{2}{*}{ SL 64} & $3.57 \mathrm{ab}$ & $2.0 \mathrm{ab}$ & $0.50 \mathrm{~b}$ & $0.34 \mathrm{~cd}$ & $2.40 \mathrm{~cd}$ & $2.2 \mathrm{~b}$ & $0.34 \mathrm{~b}$ & $2.7 \mathrm{c}$ & $0.208 \mathrm{c}$ & $0.54 \mathrm{~d}$ \\
\hline & \multicolumn{2}{|c|}{$\mathrm{Fe}$} & \multicolumn{2}{|r|}{$\mathrm{Mn}$} & \multicolumn{2}{|c|}{$\mathrm{Zn}$} & \multicolumn{2}{|c|}{$\mathrm{Na}$} & \multicolumn{2}{|c|}{$\mathrm{Cu}$} \\
\hline Rootstock & Flower & Leaf & Flow & Leaf & Flower & Leaf & Flower & Leaf & Flower & Leaf \\
\hline CAB 6P & $59.6 \mathrm{a}$ & $61.6 \mathrm{ab}$ & 23.5 & de $74.2 \mathrm{e}$ & $63.8 \mathrm{~d}$ & $49.2 \mathrm{a}$ & $1.3 \mathrm{E}-02 \mathrm{ab}$ & $1.2 \mathrm{E}-02 \mathrm{a}$ & $26.2 \mathrm{bc}$ & $11.0 \mathrm{~b}$ \\
\hline CAB $11 \mathrm{E}$ & $75.5 \mathrm{~b}$ & $72.3 \mathrm{bc}$ & 25.8 & $74.8 \mathrm{e}$ & $62.3 \mathrm{~cd}$ & $31.8 \mathrm{a}$ & $2.2 \mathrm{E}-02 \mathrm{c}$ & $9.9 \mathrm{E}-03 \mathrm{a}$ & $23.8 \mathrm{abc}$ & $10.3 \mathrm{~b}$ \\
\hline MM 9 & $62.0 \mathrm{a}$ & $71.2 \mathrm{bc}$ & 22.8 & $66.0 \mathrm{~d}$ & $61.5 \mathrm{bcd}$ & $32.5 \mathrm{a}$ & $1.5 \mathrm{E}-02 \mathrm{abc}$ & $1.4 \mathrm{E}-02 \mathrm{a}$ & $22.5 \mathrm{abc}$ & $13.4 \mathrm{c}$ \\
\hline MaxMa 14 & $60.5 \mathrm{a}$ & $64.5 \mathrm{bc}$ & 15.0 & ab $\quad 50.8 \mathrm{~b}$ & $61.8 \mathrm{~cd}$ & $51.3 \mathrm{a}$ & $1.7 \mathrm{E}-02 \mathrm{abc}$ & $1.1 \mathrm{E}-02 \mathrm{a}$ & $23.3 \mathrm{abc}$ & $10.3 \mathrm{~b}$ \\
\hline MaxMa 97 & $68.8 \mathrm{ab}$ & $74.6 \mathrm{c}$ & 12.6 & $34.0 \mathrm{a}$ & 54.4 a & $37.8 \mathrm{a}$ & $9.3 \mathrm{E}-03 \mathrm{a}$ & $1.0 \mathrm{E}-02 \mathrm{a}$ & $21.8 \mathrm{ab}$ & $11.8 \mathrm{bc}$ \\
\hline Damil & $64.6 \mathrm{ab}$ & $51.7 \mathrm{a}$ & 21.2 & $61.4 \mathrm{~cd}$ & $59.0 \mathrm{bc}$ & $38.6 \mathrm{a}$ & $1.8 \mathrm{E}-02 \mathrm{bc}$ & $1.2 \mathrm{E}-02 \mathrm{a}$ & $21.5 \mathrm{ab}$ & $8.2 \mathrm{a}$ \\
\hline Colt & $63.8 \mathrm{a}$ & $63.0 \mathrm{bc}$ & 19.8 & $51.0 \mathrm{~b}$ & $58.0 \mathrm{~b}$ & $36.6 \mathrm{a}$ & $9.4 \mathrm{E}-03 \mathrm{a}$ & $1.1 \mathrm{E}-02 \mathrm{a}$ & $20.2 \mathrm{a}$ & $8.0 \mathrm{a}$ \\
\hline SL 64 & $93.3 \mathrm{c}$ & $67.8 \mathrm{bc}$ & 16.0 & $54.8 \mathrm{bc}$ & $62.0 \mathrm{~cd}$ & $38.0 \mathrm{a}$ & $1.8 \mathrm{E}-02 \mathrm{bc}$ & $9.2 \mathrm{E}-03 \mathrm{a}$ & $27.5 \mathrm{c}$ & $11.0 \mathrm{~b}$ \\
\hline
\end{tabular}

Mean separation within columns by Duncan's multiple range test at $p \leq 0.05$. 
Figure 1. Rootstock effects on the total chlorophyll concentration of 'Sunburst' sweet cherry leaves, at the 12th year after grafting. Vertical lines indicate LSD $(P \leq 0.05)$.

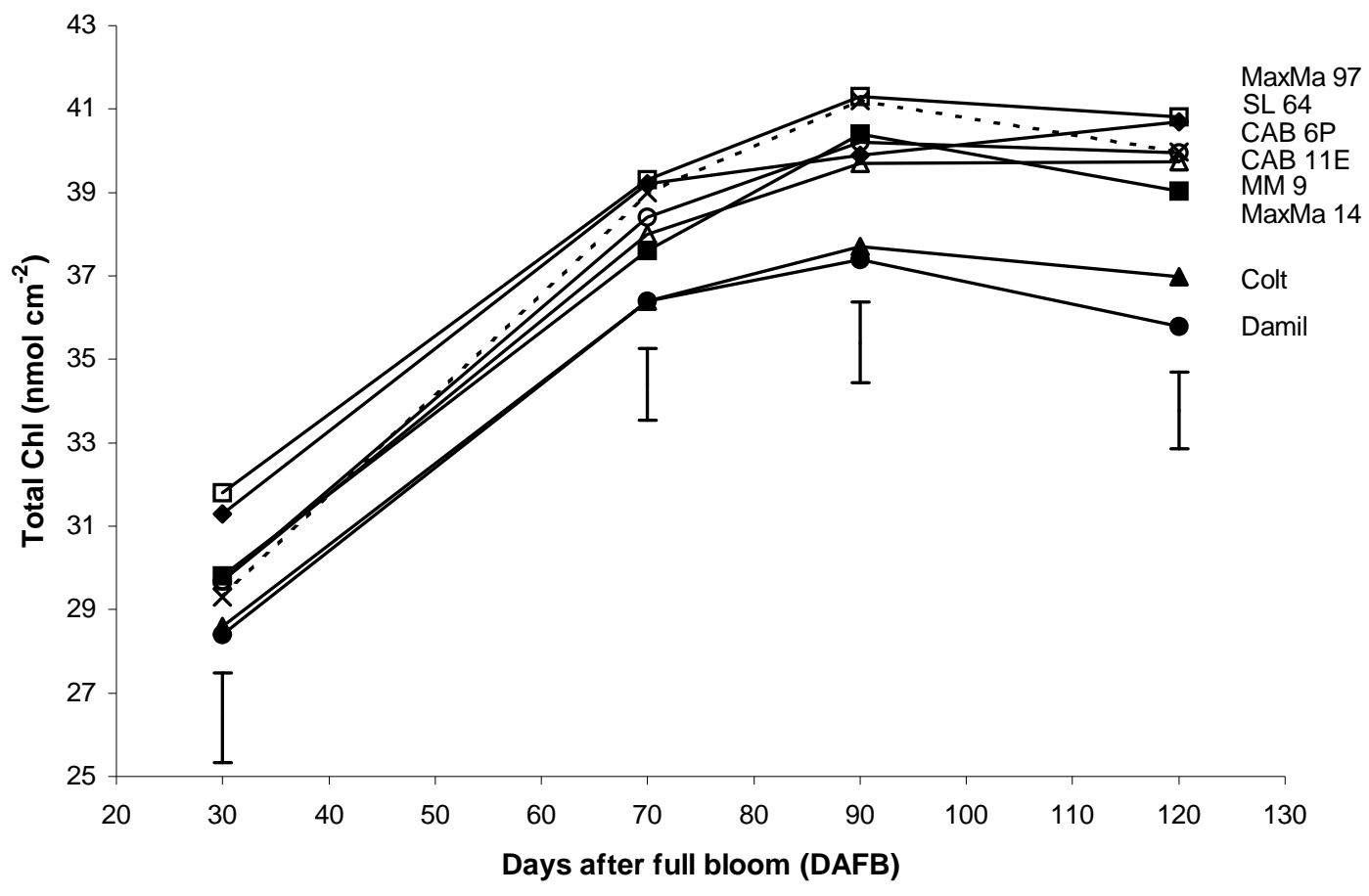


Figure 2. Correlation between flower and leaf Mn concentration per tree in 'Sunburst' sweet cherry grafted on different rootstocks.

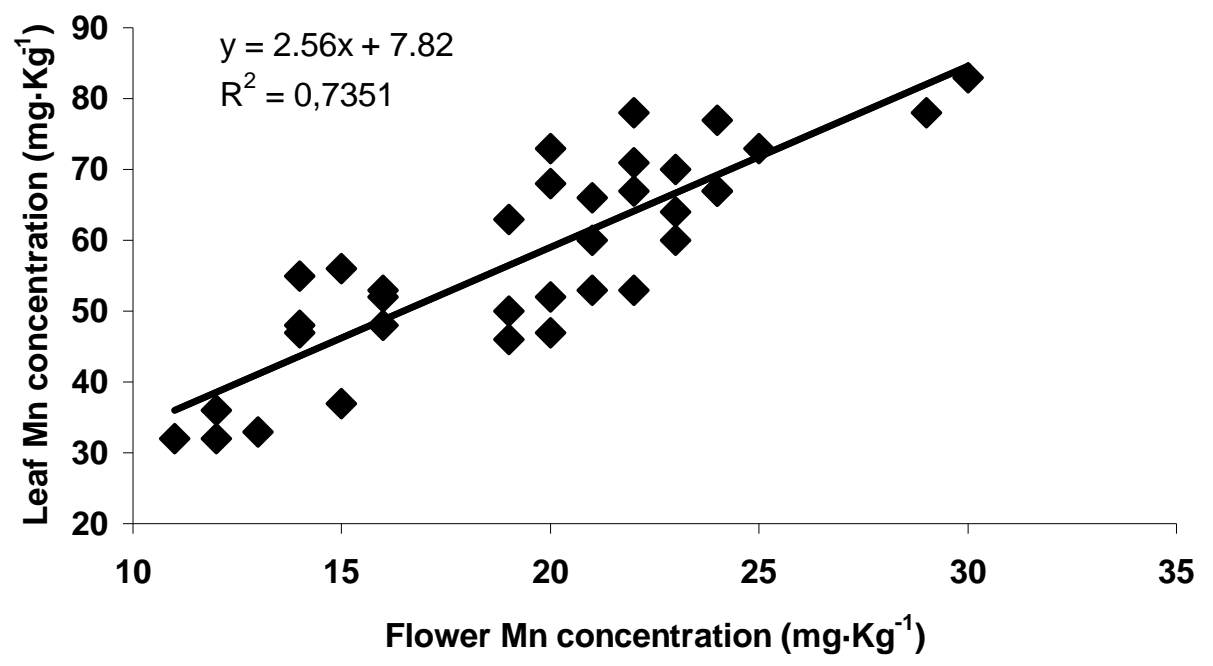

